\title{
Mind tools contributing to an ICT-rich learning environment for technology education in primary schools
}

Citation for published version (APA):

Slangen, L. A. M. P., \& Sloep, P. (2005). Mind tools contributing to an ICT-rich learning environment for technology education in primary schools. International Journal of Continuing Engineering Education and LifeLong Learning, 15(3-6), 225-239. https://doi.org/10.1504/IJCEELL.2005.007712

\section{DOI:}

10.1504/IJCEELL.2005.007712

Document status and date:

Published: 13/04/2005

Document Version:

Peer reviewed version

Please check the document version of this publication:

- A submitted manuscript is the version of the article upon submission and before peer-review. There can be important differences between the submitted version and the official published version of record. People interested in the research are advised to contact the author for the final version of the publication, or visit the DOI to the publisher's website.

- The final author version and the galley proof are versions of the publication after peer review.

- The final published version features the final layout of the paper including the volume, issue and page numbers.

Link to publication

\section{General rights}

Copyright and moral rights for the publications made accessible in the public portal are retained by the authors and/or other copyright owners and it is a condition of accessing publications that users recognise and abide by the legal requirements associated with these rights.

- Users may download and print one copy of any publication from the public portal for the purpose of private study or research.

- You may not further distribute the material or use it for any profit-making activity or commercial gain

- You may freely distribute the URL identifying the publication in the public portal.

If the publication is distributed under the terms of Article 25fa of the Dutch Copyright Act, indicated by the "Taverne" license above, please follow below link for the End User Agreement:

https://www.ou.nl/taverne-agreement

Take down policy

If you believe that this document breaches copyright please contact us at:

pure-support@ou.nl

providing details and we will investigate your claim.

Downloaded from https://research.ou.nl/ on date: 26 Apr. 2023 


\title{
Mind tools contributing to an ICT-rich learning environment for technology education in primary schools
}

\section{Lou A.M.P. Slangen*}

School for Teacher Training,

Fontys University of Professional Education, Burg,

Geuljanslaan 16, 6041 NB Roermond, The Netherlands

E-mail: 1.slangen@fontys.nl

${ }^{*}$ Corresponding author

\section{Peter B. Sloep}

School for Teacher Training,

Fontys University of Professional Education,

Mgr. Claessensstraat 4, 6130 AN Sittard,

Netherlands Educational Technology Expertise Centre,

Open University Netherlands,

171 Valkenburgerweg, 6401 DL Heerlen, The Netherlands

E-mail: peter.sloep@ou.nl

\begin{abstract}
This paper examines how the learning environment in primary education can be enhanced by stimulating the use of innovative ICT applications. In particular, this discussion focuses on mind tools as a means of leveraging ICT for the development of cognitive skills. The stimulating effect of mind tools on the thinking skills and thinking attitudes of students is examined. The various types of mind tools and a number of specific examples are closely examined. We consider how mind tools can contribute to the establishment of an ICT-rich learning environment within the domain of technology education in primary schools. We illustrate two specific applications of such mind tools and discuss how these contribute to the development of thinking skills.
\end{abstract}

Keywords: mind tools; thinking skills; habits of the mind; ICT and technology; technologica; kidspiration.

Reference to this paper should be made as follows: Slangen, L.A.M.P. and Sloep, P.B. (2005) 'Mind tools contributing to an ICT-rich learning environment for technology education in primary schools', Int. J. Cont. Engineering Education and Lifelong Learning, Vol. 15, Nos. 3-6, pp.225-239.

Biographical notes: Lou Slangen obtained a master degree in Educational Science at the University of Utrecht. He is Senior Lecturer at Fontys PABO Limburg (School for Teacher Training) in the Netherlands and is a member of the research group 'Educational Functions of ICT'. His work focuses on the implementation of ICT and technology in primary education and teacher training as well the implementation of electronic learning environments in teacher training. His research focuses on the domains of mind tools and technology. 
Peter B. Sloep obtained a master degree in Biology at the Free University, Amsterdam and a $\mathrm{PhD}$ in theoretical biology from the University of Groningen, both in the Netherlands. He currently holds a Chair in Educational Functions of ICT at the Fontys School for Teacher Training and is an Associate Professor at Educational Technology Expertise Centre of the Open University of the Netherlands. His research interests include the use of technology to support education, in particular learning objects, mind tools, learning networks, learning technology standards, and software agents.

\section{Introduction}

We see that an ever-growing number of primary schools have all of the provisions in place for the fundamental use of ICT. They have enough hardware and software, they have a handle on the pedagogical organisation, and the teachers possess sufficient personal ICT proficiency. But that is not enough. Teachers often indicate that they still have too little knowledge regarding the pedagogical aspects of the advanced use of ICT. We add that this is supported by Simons (2002) who contends that there is still considerable expertise to be developed in the area of computer-related pedagogy. The challenge for the future is, therefore, to test and research applications of ICT in more open learning situations to achieve a richer learning experience. Educational programs for teachers should train students to deploy ICT as a cognitive tool, also known as 'mind tools' (van den Dool and Kirschner, 2003).

In modern educational approaches, students are to a greater degree responsible for their own learning and the teachers focus on the development of thinking (creative, logical, and critical), the students' search for and selection of information, and on individual and collaborative work situations. This sort of education provides room for students to actually participate and to enter into an active, constructive process with learning how to learn as the primary goal.

If we want to achieve all of the objectives mentioned above, we cannot limit ourselves to the creation of ICT-sober learning situations. Boekaerts and Simons (1993) observed that the simple courseware applied in these situations does not stimulate activity in minds, but rather in the computer. We see primary schools making reluctant attempts to implement applications that are consistent with an ICT-rich learning environment, often in the form of progressive ICT use within the current curriculum. In doing so, instructors encounter all sorts of unanswered questions. The lack of a well-formed pedagogical plan that can provide answers to these questions is a deficiency. It is, after all, the teachers' responsibility to seek the educational value of their efforts. With regard to the application of ICT this is no different. Certainly when the effects cannot be directly measured, a fundamental distrust for the introduction of ICT develops.

The more closely the application of ICT interfaces with existing educational practices, the more easily its effects can be measured. The danger in this, however, is that mainly ICT applications will be put into use in the most favourable of circumstances as nothing more than a substitute for what is already taking place. ICT as a replacement for routine tasks of the instructor is pedagogically and organisationally very clear. In this vein, we saw during the 1990s how relatively quickly drill-and-practice programs for mental arithmetic in primary education were adopted in addition to and as a replacement for rows of numbers on paper. 
It is thus high time to search for a clarification of the added value of modern forms of ICT usage. This added value will hopefully translate into a transition or, better yet, even a transformation in education (de Wolf, 1998). In this paper, we will examine the value added by the application of modern ICT in schools. Through the use of examples we will demonstrate how these progressive ICT applications can deliver an appropriate pedagogical contribution to a relatively new field of interest in Dutch primary education, specifically in technology education, from which it will find its way in due course to other educational areas. Thereafter, we take a look at how specific applications of ICT and technology can function as 'mind tools'.

\section{Mind tools, a first investigation}

Mind tools are an aid that helps to stimulate critical thinking: tools for the cognition (Jonassen, 2000). With this statement, we make immediately clear that mind tools are not only computer applications. An electronics kit that contains many opportunities for experimentation and provides room to develop insight and knowledge can fulfil the same function as a computer program. Many modern computer applications are, however, well suited to serve the role of mind tools. Essentially, the learner uses the computer program in such a way that he or she creates a representation of what is being studied. Mind tools activate constructivist, higher-order, critical thinking. What is essential is that the learner interprets information and begins to organise his or her knowledge in a different manner. Mind tools provide assistance for reasoning related to content and provide possibilities for working with causal relationships and forms of analytical thinking. Students only begin using mind tools properly when they are encouraged to think critically about the subject matter they are studying.

Mind tools are not technical aids used to present subject matter that the student is consequently expected to reproduce. They are a means that allow the student to actively participate and manipulate the technology to increase self-knowledge and develop forms of reasoning. This development is not limited to the domain-specific knowledge that is contained in the technological resource; it also generates more generalised thinking skills and strategies.

This process of manipulation with a mind tool can occur in an individual situation, as well as in an interactive dialogue with others. According to the literature (Dam and Volman, 2002), the latter appears to deserve the preference. Language appears to be an important factor in the construction of knowledge and the acquisition of insights (Wells, 2002). This language-based interaction must be goal oriented though, solving a problem together for instance, and be based on the development of new knowledge. According to this conception, based on what is called 'progressive discourse' by Bereiter (1994), the various participants constantly provide suppositions, explore ideas, investigate the alternatives, and search for explanations or solutions that contribute towards progress in the solution of the problem. Learning through the manipulation of a mind tool is better supported when a language dialogue is possible with another learner. A student who puts his thoughts into words makes his thinking process explicit so that another can react to that process. This language-based interaction can take place by working together with the mind tool. The mind tool can also serve as an environment, in which knowledge is developed together, as is the case with 'mind bridges' (Chee, 1997), a multimedia environment specially designed to activate thinking processes. 
In summary: mind tools do not make learning easier, but they do make it better. They compel the learner to manipulate knowledge more intensively and in greater depth. And that leads us to the question what exactly constitutes those cognitive manipulations.

\subsection{Learning, mind tools, and habits of the mind}

During the past decade we have seen that the ICT has had an enormous influence on research and society, a very strong reorientation of people's conceptions of learning, the learner, and the role of the school. Kok (2003) describes a number of movements that have had an influence on theories about learning and teaching during the past century. What these movements have in common according to him is that children, of their own volition, can learn wherever an interaction with their surroundings is possible. It is, however, the richness of the surroundings that primarily determines what the child learns. This view is strongly supported by changing views on intelligence. There is much reason to believe that intelligence is not static but, rather, can be developed and trained (Costa and Kallick, 2002).

Applying mind tools to allow children to learn comes down to providing a (rich) environment, in which the pupil can construct knowledge and can reflect upon his interactions and thinking. The constructivist presumes that we develop mental models and adapt these to provide room for new experiences. This also indicates that learning implies the initiation of a thinking process; this is preferably a process that we share with others. A lot of research has been carried out on this sort of thinking process during recent decades. Jonassen (2000) employs the 'integrated thinking model' of the Iowa department of education (Figure 1) to provide a description. This model is assembled from the following components:

- content/basic thinking, which has to do with the skills, attitudes, and dispositions required to acquire accepted knowledge

- critical thinking(analysing), which is defined as the dynamic reorganisation of knowledge in a meaningful and usable manner

- creative thinking(synthesising), which includes surpassing the accepted knowledge to generate new knowledge

- complex thinking, which originates when the basic components content thinking, critical thinking, and creative thinking that is the accepted, the reorganised, and the generated knowledge, are deliberately integrated to achieve a specific goal.

Teachers search continually within the limits of the current curriculum for opportunities to teach children thinking skills. The contemporary education methods, through their nature and use, hardly lead to processes of critical or creative thinking, let alone to the complex thinking skills of the integrated thinking model. In many methods, learning is guided through the distribution of information and assignments. Seldom is the starting point of learning sought in challenging, activating situations that appeal to the attention and interests of students, for example, the problem solving, designing, or decision making situations that the integrated thinking model describes under 'content/basic thinking'. The complex thinking processes are based on the goal-directed integration of accepted, reorganised, and generated knowledge (Figure 1). When the teaching of underlying thinking skills occurs in isolation, one does not develop the habit of applying these skills to new situations. 
Figure 1 Integrated thinking model

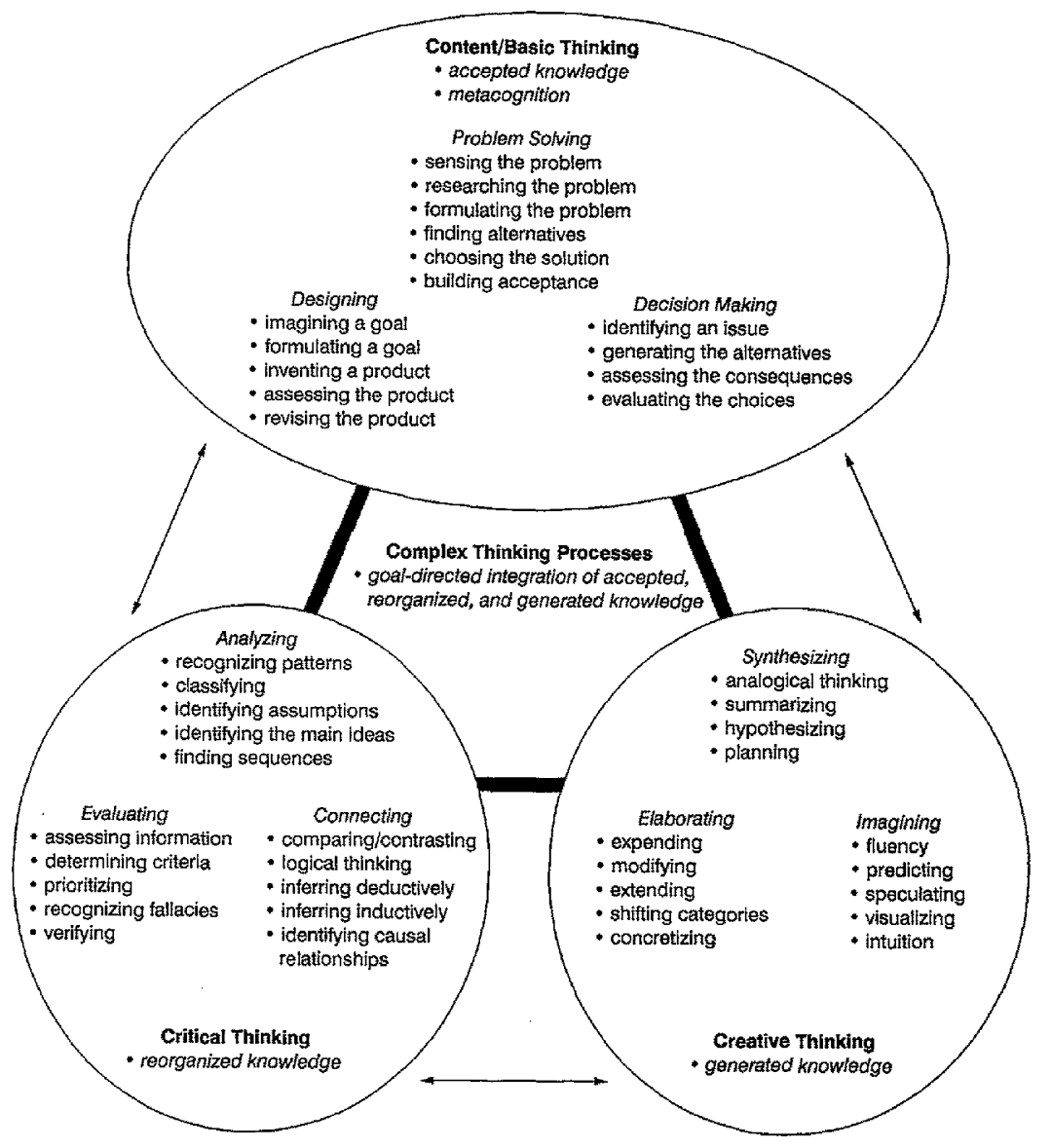

Source: Jonassen (2000)

For this purpose, Costa and Kallick (2002) define the concept of a 'habit of mind'. It consists of skills, attitudes, cues, past experiences, and proclivities. In their view, intellectual behaviour is always based on combinations of choices determined by the situation, which lead to a certain intellectual pattern. It is, therefore, necessary to expose students to a demanding intellectual environment for an extended period of time. In such surroundings, attention can be given to the teaching of habits to the mind. Altogether, this demands a fundamentally different perspective on the role of 'presented' education. Education should lead to children's development of cognitive strategies by constantly compelling them to formulate questions, face challenges, seek solutions, explain concepts, answer questions, substantiate reasoning, and retrieve information. The 'generative science teaching' approach formulated by Wittrock (1994) with its emphasis on productive learning processes, fosters this kind of education. Wittrock lets students revise their own models and concepts on the basis of active learning endeavours. These endeavours confront students with the scope and (im)possibilities of their own model. By setting goals that cannot be achieved too quickly but which do result in 
gradual, visible progress, the students are continually motivated to reformulate their perceptions. This results in more profound learning.

Costa (2002) describes the following 16 habits of mind:

- persisting

- managing impulsivity

- listening with understanding and empathy

- thinking flexibly

- thinking about thinking (metacognition)

- striving for accuracy

- questioning and posing problems

- applying past knowledge to new situations

- thinking and communicating with clarity and precision

- gathering data through all senses

- creating, imagining, innovating

- responding with wonderment and awe

- taking responsible risks

- finding humour

- thinking interdependently

- remaining open to continuous learning.

While the Iowa model involves the integration of a number of fundamental thinking skills, Costa seeks the expression of characteristic behaviours that are conditioned to allow the thinking skills to be optimally utilised. If the educational system wishes to achieve the correct application of thinking skills, it is inevitable that a fundamentally new philosophy will have to guide the manner in which the available educational instruments are employed. That philosophy begins with the stimulation of the sort of behaviour that Costa describes, with its attempts to initiate in students the complex forms of thinking that develop from an accepted knowledge base and from considering information critically and creatively. As mentioned earlier, the fundamental idea is that intelligence is not static but that it can grow. Mind tools are the sort of tools that stimulate such growth.

From our first explorative experiments with the use of mind tools in education, we received signals that pupils were learning in a different manner. A detailed description of what and how they learn is not yet available. Our observations, however, dovetail with the supposition of Jonassen et al. (2003) that mind tools make learning more meaningful. These authors claim that the implementation of mind tools contributes to learning based on the characteristics of meaningful learning; in this case that amounts to

- active (manipulative/observational) learning

- constructive (articulate/reflective) learning

- intentional (reflective/regulative) learning

- authentic (complex/contextual) learning

- cooperative (collaborative/conversational) learning. 


\section{Mind tools further classified}

Before delving into the manner in which mind tools can be used in education, by way of setting the stage, we discuss the categorisation of mind tools according to Jonassen et al. (1998) and provide a number of examples.

\subsection{Semantic organisation tools}

Semantic organisation tools help the learner to analyse and organise semantic, meaningful information. The two most familiar applications are database programs and various tools for building semantic networks.

Both during the construction and structuring of a database, as well as during its use, the user must ask himself questions: What do I want to use it for? For what type of questions should the contents provide answers? How must I phrase the questions to access the knowledge? How can I use the fields and which fields should I use?

Semantic networks provide a representation (often visual) of meaningful interrelationships between concepts. Through the use of symbols, a conceptual network is built around an idea - the time-honoured 'word web'. The nature of the relationships and the form, which they are given are determined by the learner. Through structuring and restructuring, the learner actively builds a personal knowledge domain and learns to analyse, describe, and see past the relationships. See Figure 2 for an example.

Figure 2 Mindmap designed with 'Kidspiration software'

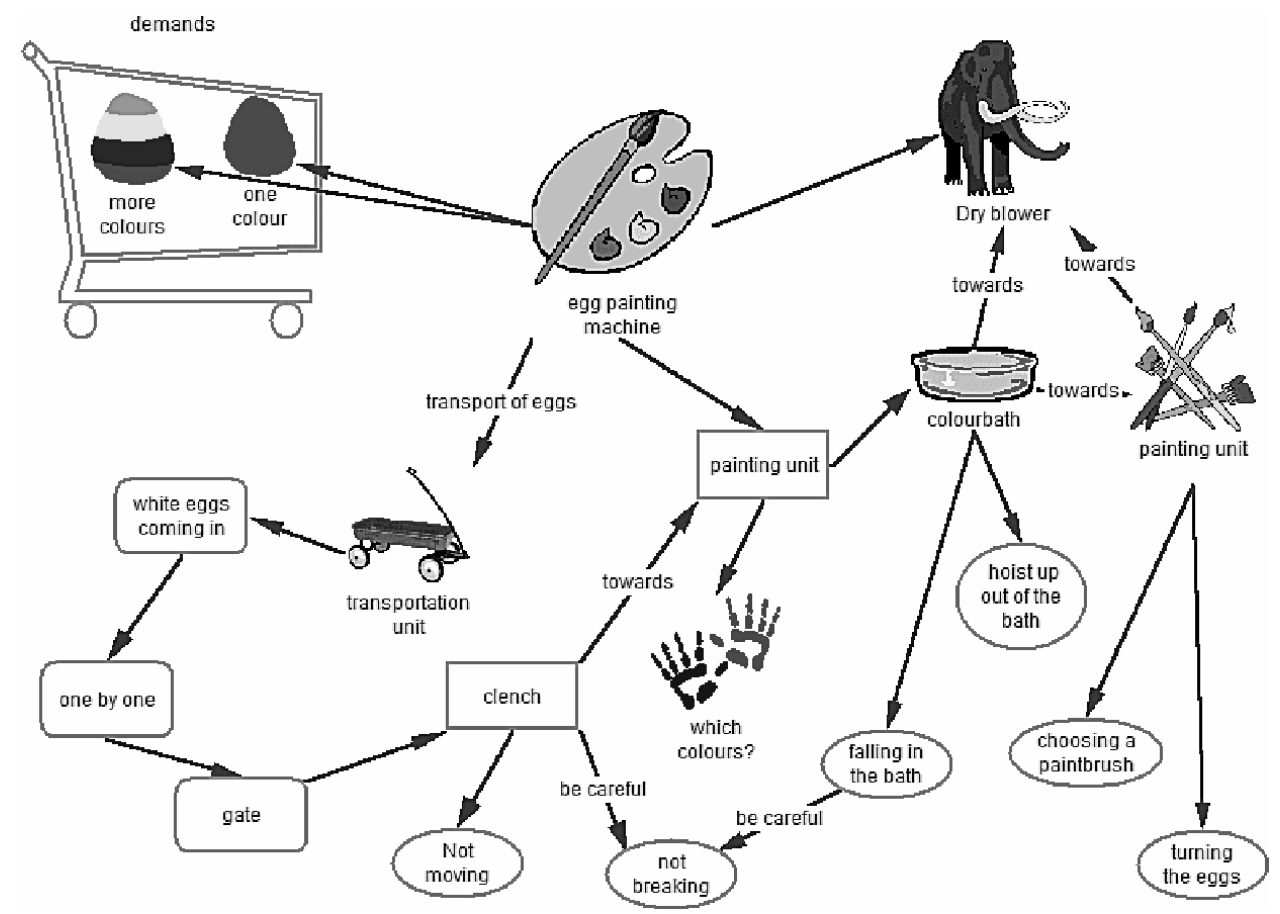




\subsection{Dynamic modelling tools}

Dynamic modelling tools help the learner to describe, manipulate, and expand upon the dynamic relationships among ideas. This category includes various tools that make dynamic mathematical models accessible for non-mathematicians. Nevertheless, models of this type very quickly become quite complex (see, for example, Doucet and Sloep, (1992)). The simplest examples are spreadsheets and, particularly, the so-called micro worlds.

Building a model of reality in mathematical terms requires a large measure of abstract reasoning and is closely related to mathematical and logical thinking. The strength of models in this category is that they offer more than a calculator because they make the relationships between the variables visible. This is also true for spreadsheets. This type of models lets the user ponder how a problem can best be approached and how a series of decisions can best be structured.

Micro worlds are small (partial) virtual worlds in which the learner can navigate, make decisions, experience consequences, expand ideas, and so forth. Often they are limited simulations of real world situations. Micro worlds are possibly the most pregnant example of active learning environments. They are very popular with young people. Many of these worlds are derived from a basis in mathematics, physics, technology, or information science. Two well-known examples are SimCity and Logo.

Krumholtz and Markuze-Haas (1998) and Krumholtz (1998) describe the micro world 'Techno-Logic' that is especially suitable for use in primary education. It is a physical (external) micro world, for example, a toy consisting of a collection of electromechanical components (construction material with motors and sensors) that is controlled by a computer. Techno-Logic integrates creative construction of physical machines and models with a computer-based process controller that is made accessible through an interface. In this micro world, children can examine and experiment with physics concepts and their applications in technology. Techno-Logic is a mind tool that offers many opportunities to provide practice in problem solving and to aid in the development of thinking skills and habits of the mind. Figure 3 shows a screen capture of the TechnoLogica control software for this micro world.

Figure 3 screen capture of the TechnoLogica control software for the interface Leonardo

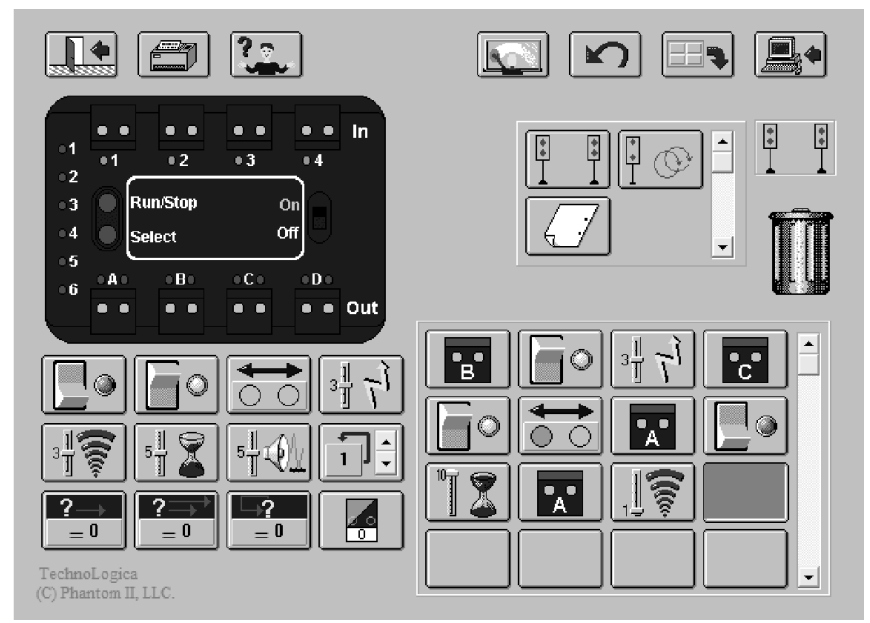




\subsection{Information interpretation tools}

Information interpretation tools help make information more accessible for learners and assist them in processing that information. This category includes search engines, hypermedia, and weblogs (blogs).

Search engines offer the learner a chance to gather information in a systematic and logical manner. The process of determining the correct search parameters through a series of refinements is well suited to the assimilation of thinking skills.

Hypermedia consists of information links that serve to make information stored in any form (video, text, image) accessible. A user can add or change information to create links.. In its entirety, it becomes a dynamic knowledge base. The idea that making this sort of (instructional) material teaches more than using it is supported by ThinkQuest, where children can make their own websites. This is, by the way, one of the most common examples of the use of mind tools in the Netherlands. The idea that it is not the website (the product) but rather that the creator learns during the development, construction, and content creation of an educational website (the process) is, unfortunately, often contended. We observe that in daily practice the website (the product) is mostly seen as the goal instead of as a means of learning (the process), or we see that mastering the tools (software used to make websites) is seen as the ultimate learning goal.

Blogs are a special sort of webpage intended for (restricted) public use (Poortman and Sloep, 2005). A diary format is typical. Mostly the contents include short, regularly updated messages in inverse chronological order. These pages can include all sorts of things, such as links, information blocks, diary entries, photos, project updates, and so on. Some blogs are personal, and others are the result of collaborative work. With special tools, blogs can be given extra functionality. They are interesting in the framework of managing dynamic information, but in addition they also serve a clear communicative function.

\subsection{Conversation tools}

Conversation tools are appropriate for learning through discussion. They make use of communication techniques that are useful for negotiation, careful consideration of contributions, synthesis, and inclusive and exclusive thought. Examples of this type of application are instant messaging, email, forums or discussion boards, and once again blogs (assuming they are supplemented with support for threaded discussions among visitors).

Instant messaging is a synchronous conferencing application. The number of participants is theoretically unlimited, although there is a practical limit of approximately five per session. Properly used, this resource can be used to teach, argument, and reasoning. At present, this application is used very intensively by young people, primarily for private communication. Specifically, because of the synchronous nature of the communication there is little time for extensive deliberation. The participant is thus compelled to think and react quickly.

E-mail and discussion boards are asynchronous means of communication. Like instant messaging they offer a forum for argumentation and reasoning, but in contrast these tools emphasise careful consideration and formulation. 


\section{Introducing mind tools to primary education in The Netherlands with technology as platform}

Although the desire that more attention be directed towards the learning processes, the learning of thinking skills (Meer van der and Nuyens, 2002), cooperative learning, and constructivist learning is repeatedly heard within the Dutch education community, we see that ICT applications that could make this possible are only sporadically employed in daily teaching practices. Too little concept of the practical interpretation of such an ICT-rich learning environment, unfamiliarity with the possibilities, and the added value of such an approach, as well as inexperience with the application of ICT are probably to blame. It requires an unconventional approach from teachers to implement such instruments, and within the prevailing educational situation there are but few incentives to follow this path. We are not, incidentally, dealing with innovation in the area of educational equipment any more. We have already established after all that both the facilities, as well as training in the use of ICT are at or above the required levels. ICT-rich learning environments require more. They presume an optimal balance between learning and teaching, a constructivist vision of that balance, and once again an appropriate pedagogical approach from the instructor. The domain encompassed by technology education can serve as a suitable platform.

Technology as a content area for achieving educational goals has long been out of fashion in Dutch primary education. In recent years, it has become a focus in the educational reforms of primary education. The explicit attention for this domain of learning provides a plethora of chances to redirect the orientation of those providing instruction from traditional ICT use towards new applications of ICT. For the pupils, this means that they can make use of advanced technological tools that allow them to go beyond the borders of classical learning tools and methods. Virtual worlds created by mind tools make the unknown conceivable and visible, and allow it to be manipulated. In this way, these tools support in particular the need of young students to have abstract ideas demonstrated through concrete examples to aid in their understanding.

Just as with insights about modern ICT usage, the recent notions about responsible technology education are primarily fed by educational concepts associated with the 'new learning', such as constructivism, brain-based learning and multiple intelligence, cooperative learning and learning styles (Slangen, 2005). The teaching of technology employs to this end such key concepts as problem solving, (re)design, producing, researching, analysing, evaluating, and reflecting, in which both the product and the learning process are equally important. Mind tools can serve well as learning tools for the development of (technical) thinking skills. Then again, mind tools as instruments (software) are themselves the result of modern technology.

Teachers are not only expected to carry out the established educational plan, they are also expected to function as developer of learning environments and improver of education (Wubbels, 2002). For students of education, it is therefore, clear that they will come into contact with this aspect of the profession. Schools focus more and more attention on the development of educational programs that are directed towards knowledge development and the coupling of theory and practice; in these the student is both researcher and developer of education. In this framework, students with a specialisation in technology and ICT can serve as catalysts for the implementation of new applications in these areas during their internships. 


\section{A further look at several mind tools}

With the expectation that various mind tools contribute to the development of the (technical) thinking abilities of children, these have been implemented during the internship period of student teachers to develop an ICT-rich learning environment for technology. We illustrate, with two concrete examples, how mind tools contribute to technical thinking skills.

\subsection{Kidspiration}

Skills that are important within the content domain of technology involve learning to solve technical problems and learning to design based on these solutions. Development skills and problem solving skills are called upon in a continuous cycle. In the beginning phase of development, processes are based on many different thinking skills, but these tend to be concentrated in the creative range. Later, thinking skills of a more critical nature are needed. Developing a good design often demands, at the start, both free association and departure from established thinking. Creating the design requires (re)organisation of information into new, meaningful arrangements and entities. Additionally, it involves analysis, (re)grouping and organisation according to various criteria, further refinement of parts of the design, and so forth.

The development of new technology or the redesign of existing technology entails the use of known data, generation of new information, and the reorganisation of data and information. It involves, in other words, a continual process of semantic organisation. Explicit external representations, such as concept maps, to support association and conceptualisation lead to the formation of new ideas - in other words, to learning (Lavik and Nordeng, 2004; Kommers, 2004). Specifically, graphical representation offers the brain significant support for the application of semantic organisation and the development of thinking. According to Buzan (1991), activating the entire brain requires not only words, numbers, structures, sequences, and lines, but also colour, figures, dimensions, symbols, and visual rhythms that is, mindmaps. Mindmaps are representations of semantic concepts. Modern mind mapping software is, therefore, considered to be one of the most powerful instruments for semantic organisation and the active and efficient creation and manipulation of representations. Mindmapping software can, for this reason, be widely deployed in education, in every situation that involves the generation of ideas.

Kidspiration falls under the umbrella of semantic organisation mind tools and is primarily suitable to assist young children in brainstorming, after which the output can be organised in more systematic diagrams that can be further used to create development and planning diagrams. It assists in the learning of thinking, writing, and understanding through the creation of diagrams with illustrations, text, symbols, and spoken words. In this process, they make their ideas visible and show the interrelationships. Within the graphical display children build, for example, groups, word webs, association diagrams, or conceptual maps. Thereafter, they carry their work over to a notebook where their ideas can be further refined in words, leading to crystallisation of the design.

Figure 2 shows the results of a first brainstorm, within the domain of technology, for the development of an egg painting machine. After this first round of creative thinking, more organised and refined actions must be applied to the mindmap. 


\subsection{The techno-logic micro world as mind tool}

Techno-Logic can be described as a mind tool with which children learn physics concepts and can explore and apply their technological applications. TechnoLogic offers possibilities, in the right educational setting, to transition from learning problem solving to the development of thinking skills and habits. Characteristic of this micro world is that it is manifested in the physical world, but studied through a computer. In a problem-solving educational setting, the Techno-Logic world invites active manipulation, in which feedback through testing of the model, statement of hypotheses, analysis of the problem, and the search for causal relationships continually stimulate critical thinking processes (Figure 4).

TechnoLogica is the software with which a working model of some machine is controlled. Its most prominent part is the interface 'Leonardo'. It has four ports that control devices such as motors or lamps. There are also four inputs for the connection of various types of sensors (temperature sensor, magnetic sensor, etc.) that can provide feedback on the basis of which the computer can make decisions, carry out actions, and so forth. For example: Stop the car of the Ferris wheel for five seconds, rotate the wheel to the following car, and so on. Once all of the cars have passed, the start signal is activated for three seconds, the lamps begin to flash quickly, and the wheel begins to turn. The development of a control procedure in the computer program occurs through the placement of various action buttons, sensors, ports, and decision junctions in a specific order. In addition, buttons can be created that contain procedures. We see here strong similarities to the programming language Logo (Papert, 1993). The program is developed in such a way that it does not require much programming knowledge but rather initiates a thinking process.

Figure 4 Programming TechnoLogica software and the interface Leonardo in a school project the fair

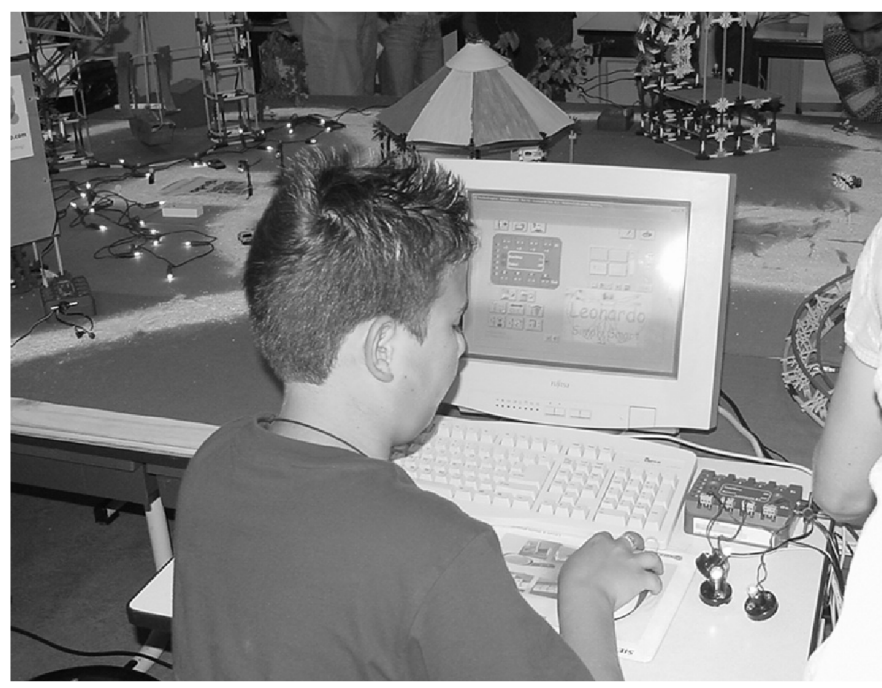

Writing such a control procedure requires a large measure of logical, critical, and creative thinking from children. On the basis of practical experiments in primary schools, we ascertain that this sort of technical activities calls greatly upon thinking skills 
(causal relationship concepts, comprehension of parallel and serial processes, recognition of faulty assumptions, deductive reasoning, etc.). Habits of the mind are just as rigorously exercised (flexible thinking, accurate thinking, being persistent, gathering data and using what you already know, and so forth). The development of complex control processes is an activity that places strong demands on critical, logical, and creative thinking. Based on his or her choices, the user can test the application, analyse the consequences, and try new procedures. The concrete nature of the response (something occurs in the physical model) makes it very easy for primary school children to gain insight into the application of the computer procedures. By applying them, after all, you see whether or not it works and whether you have properly thought things through. With small changes you can test and improve your thinking.

Our first experimental explorations into the possibilities for employing the mind tool Techno-Logic support the assumption that children actively engaged in dialogic interactions are intensively developing thinking skills and thinking attitudes. These observations are supported through experiences with this mind tool elsewhere (Krumholtz, 1998), in which it appears that children develop some form of technological thinking (technical concepts, research skills, and problem solving skills in a technical context).

\section{Conclusion}

Changes in education are not enacted through the implementation of new media alone (Westera and Sloep, 2001). And if the implementation of new media leads to changes, they do not take root or they do not have the desired effect (Oppenheimer, 2003). The starting point for every transition or transformation in education is a change in teacher behaviour. But we must also implement a number of strategies in education to adopt new premises about thinking, learning, instruction, progression, and teaching. This requires rich learning environments for active learning (Grabinger, 1996). Bereiter (2002) speaks in this context about 'progressive education'. We can expand on this by saying that there is a need in the day-to-day educational practice for concrete instruments that provide a practical way of putting these progressive ideas about learning and teaching into effect. The fundamental observations about this different approach to learning and teaching are certainly not new. The manner of achieving these goals, however, in recent years has gained more support through societal and educational shifts. Mind tools are among the instruments that can contribute significantly to that new educational system. Sometimes they are a generalised educational application (mindmap software), and sometimes they are more specifically developed for a particular domain, for example, technology (control software for technical applications). However, in both instances they achieve two goals:

- they help to create the desired rich learning environment that involves students in active learning

- they allow instructors to gain experience with the applications and effects of constructivist learning.

Thus, mind tools support the creation of an educational learning situation focused on the development of general thinking skills and thinking attitudes. 


\section{Acknowledgement}

We would like to thank Wim Didderen for his valuable comments on an earlier version of this paper, and Ben Hickman for his help in translating the original Dutch manuscript.

\section{References}

Bereiter, C. (1994) 'Implications of postmodernism for science, or, science as progressive discourse', Educational Psychologist, Vol. 29, No. 1, pp.3-12.

Bereiter, C. (2002) Education and Mind in the Knowledge Age, Lea, London.

Boekaerts, M. and Simons, R.J. (1993) Leren en Instructie, Psychologie van de Leerling En Het Leerproces, Dekker \& van de Vegt., Assen.

Buzan, T. (1991) Use Both Sides of Your Brain, Dutton/Plume, New York.

Chee, Y.S. (1997) 'Toward social constructivism: changing the culture of learning in schools', Proceedings of ICCE 1997, International Conference on Computers in Education, Kuching, Malaysia, Association for the Advancement of Computing in Education Charlottesville, VA, pp.81-88.

Costa, A.L. (2002) 'Denkgewoonten beschreven', in van der Meer, N. and Nuyens, T. (Eds.): Nederlandstalige uitgave, Kinderen denken leren, ontdekken en verbeteren van denkgewoonten, MENU-groep.

Costa, A.L. and Kallick, B. (2002) 'Veranderende opvattingen over intelligentie', in van der Meer, N. and Nuyens, T. (Eds.): Nederlandstalige uitgave Kinderen Denken Leren, Ontdekken en Verbeteren Van Denkgewoonten, MENU-groep.

Dam, G.T. and Volman, M. (2002) 'Het sociale karakter van kritisch denken', Pedagogische Studiën, Vol. 79, pp.167-183.

de Wolf, H. (1998) Toekomstgericht Onderwijs en Het Gebruik Van Informatie- En Communicatietechnologie, Hoe te komen tot verantwoorde keuzen?, Commissie Prommitt / Open Universiteit Nederland Samson, Heerlen.

Doucet, P. and Sloep, P.B. (1992) Mathematical Modeling in the Life Sciences, Ellis Horwood, New York etc.

Grabinger, R.S. (1996) 'Rich environments for active learning', in Jonassen, D.H. (Ed.): Handbook of Research for Educational Communications and Technology, Prentice Hall International, London.

Jonassen, D.H. (2000) Computers as Mind Tools for Schools: Engaging Critical Thinking Columbus, Prentice- Hall, Ohio.

Jonassen, D.H., Carr, C. and Hsiu-Ping, Y. (1998) 'Computers as mind tools for engaging learners in critical thinking', TechTrends, Vol. 43, No. 2, pp.24-32.

Jonassen, D.H., Howland, J.L., Moore, J.L. and Marra, R.M. (2003) Learning to Solve Problems with Technology, A Constructivist Perspective. Columbus, Merrill Prentice Hall, Ohio.

Kok, J. (2003) Talenten Transformeren, Over het Nieuwe Leren en Nieuwe Leerarrangementen, Fontys Hogescholen, Eindhoven.

Kommers, P. (2004) 'Concepts in the world of the mind', in Kommers, P. (Eds.): Cognitive Support for Learning. Imagining the Unknown, IOS Press, Amsterdam.

Krumholtz, N. (1998) 'Techno-logic: A micro-world for constructivist science and technology learning', Proceedings of the 6th Int. Conference on Computers in Education (ICCE98), Beijing, China, October 1998.

Krumholtz, N. and Markuze-Haas, A. (1998) 'Creating rich learning environment with computer technology: the learning model of 'IDEA center'. Paper presented in Int. conference on 'Learning in the 21st Century. Holland, November, <http://www.phantom2.com/idea/ papr_tch.html> 
Lavik, S. and Nordeng, T.W. (2004) 'Brainbank learning - building personal topic maps as a strategy for learning', in McIlraith, S.A., Plexousakis, D. and van Harmelen, F. (Eds): Proceedings Third International Semantic Web Conference, Hiroshima, Japan, 7-11 November 2004, Series: Lecture Notes in Computer Science, Vol. 3298, XXI, Springer, Heidelberg.

Oppenheimer, T. (2003) The Flickering Mind. The False Promise of Technology in the Classroom and How Learning Can be Saved, Random House, London.

Papert, S. (1993) 'Mindstorms: Children, Computers, and Powerful ideas', Perseus Publishers.

Poortman, S. and Sloep, P.B. (2005) 'Weblogs in het onderwijs; praktisch artikel', OnderwijsInnovatie 1, in press.

Simons, R.J. (2002) Digitale Didactiek: Hoe (Kunnen) Academici Leren ICT te Gebruiken in Het Onderwijs, Universiteit van Utrecht, Utrecht.

Slangen, L.A.M.P. (2005) 'Techniek: leren door doen', Praktische Didactiek Voor Het Basisonderwijs Baarn, HB-Uitgevers.

van den Dool, P and Kirschner, P. (2003) 'Integrating the educative functions of information and communication technology (ICT) in teachers' and learners' toolboxes: a reflection on pedagogical benchmarks for ict in teacher education', Technology, Pedagogy and Education, Vol. 112, No. 1, pp.161-179.

van der Meer, N. and Nuyens, T. (2002) 'Voorwoord van de vertalers', in van der Meer, N. and Nuyens, T. (Eds.(Nederlandstalige uitgave): Kinderen Denken Leren, Ontdekken en Verbeteren Van Denkgewoonten, MENU-groep.

Wells, G. (2002) 'Learning and teaching for understanding: The key role of collaborative knowledge building'. in Brophy, J. (Ed.): Social constructivist teaching: Affordances and constraints. Advances in Research on Teaching University of California, Santa Cruz. Elsevier/JAI. Vol. 9. pp.1-41.

Westera, W. and Sloep, P.B. (2001) 'The future of education in cyberspace', in Vandervert, L.R. Shavinina, L.V. and Cornell, R.A. (Eds.): Provocative and Do-Able Futures for CyberEducation: Leadership for the Cutting Edge Mary Ann Liebert, Publishers, Larchmont, NY, pp.115-137)

Wittrock, M.C. (1994) 'Generative science teaching', in Fensham, P. Gunstone, R. and White, R. (Eds.): The Content of Science. A Constructivist Approach to its Teaching and Learning, The Falmer Press, London.

Wubbels, T. (2002) 'Voorwoord', in Ponte, P. (Ed.) Onderwijs Van Eigen Makelij; Procesboek Actieonderzoek in Scholen En Opleiding, Nelissen BV, Soest. 